\title{
Multi-functional architectures supported on organostannoxane scaffolds
}

\author{
VADAPALLI CHANDRASEKHAR*, PALANI SASIKUMAR, PUJA SINGH, \\ RAMALINGAM THIRUMOORTHI and TAPAS SENAPATI \\ Department of Chemistry, Indian Institute of Technology Kanpur, Kanpur 208016 \\ e-mail: vc@iitk.ac.in
}

\begin{abstract}
Organostannoxane cages and aggregates of well-defined composition and structure can be prepared by the reactions of organotin oxides or organotin oxide-hydroxides with protic acids. The utility of this strategy for the preparation of dendrimer-like molecules containing a stannoxane core and a functional periphery is described.
\end{abstract}

Keywords. Organostannoxanes; organotin; multi-ferrocenes; multi-photoactive; phosphonates; pyrazole.

\section{Introduction}

In recent years there have been many efforts to explore the possibility of using inorganic ligands and cages as scaffolds for assembling star-burst type or dendrimer-like architectures. Among the family of compounds that have been investigated for this purpose include cyclophosphazenes, ${ }^{1-4}$ cyclosiloxanes, ${ }^{5-9}$ borazines, ${ }^{10-13} \mathrm{Al}-\mathrm{N}$ rings ${ }^{14-15}$ and $\mathrm{Al}-\mathrm{C}$ rings. ${ }^{16-17}$ The main strategy in this game plan is to build a central 'inorganic core' which contains several reactive sites. The latter are utilized for introducing the required functional groups. As a case in point, consider the reaction of $\mathrm{N}_{3} \mathrm{P}_{3} \mathrm{Cl}_{6}$ with $\mathrm{N}$-methylhydrazine to afford $\mathrm{N}_{3} \mathrm{P}_{3}\left[\mathrm{~N}(\mathrm{Me}) \mathrm{NH}_{2}\right]_{6}$. The latter contains six reactive $-\mathrm{NH}_{2}$ groups. These have been condensed with ferrocene aldehyde to afford the hexaferrocene derivative $\mathrm{N}_{3} \mathrm{P}_{3}\left[\mathrm{~N}(\mathrm{Me}) \mathrm{N}=\mathrm{CH}-\mathrm{C}_{5} \mathrm{H}_{4} \mathrm{FeC}_{5} \mathrm{H}_{5}\right]_{6}$ (scheme 1). ${ }^{18}$

Similarly, cyclophosphazenes and carbophosphazenes have been used for supporting multi-site coordination ligands and for preparing multimetallic assemblies. ${ }^{19-29}$ In all of these instances the construction of the star-burst like molecules occurs in a step-wise manner proceeding from a central core which has multiple pre-organized well-defined reactive sites. In many ways this strategy is similar to that is well known in the synthesis of organic dendrimers.

In contrast to the above situation, a completely new synthetic strategy entails the assembly of the central core and the periphery at the same time. In

*For correspondence this strategy there is no pre-organized central core to begin with. On the other hand, the construction of the central core mandates the simultaneous formation of the multifunctional periphery. Which type of inorganic rings or cages are amenable for this 'onepot' 'one-shot' construction of the starburst assembly? Our long experience on organostannoxanes has suggested to us that the synthesis of these compounds provides a possible route for the assembly of multi-

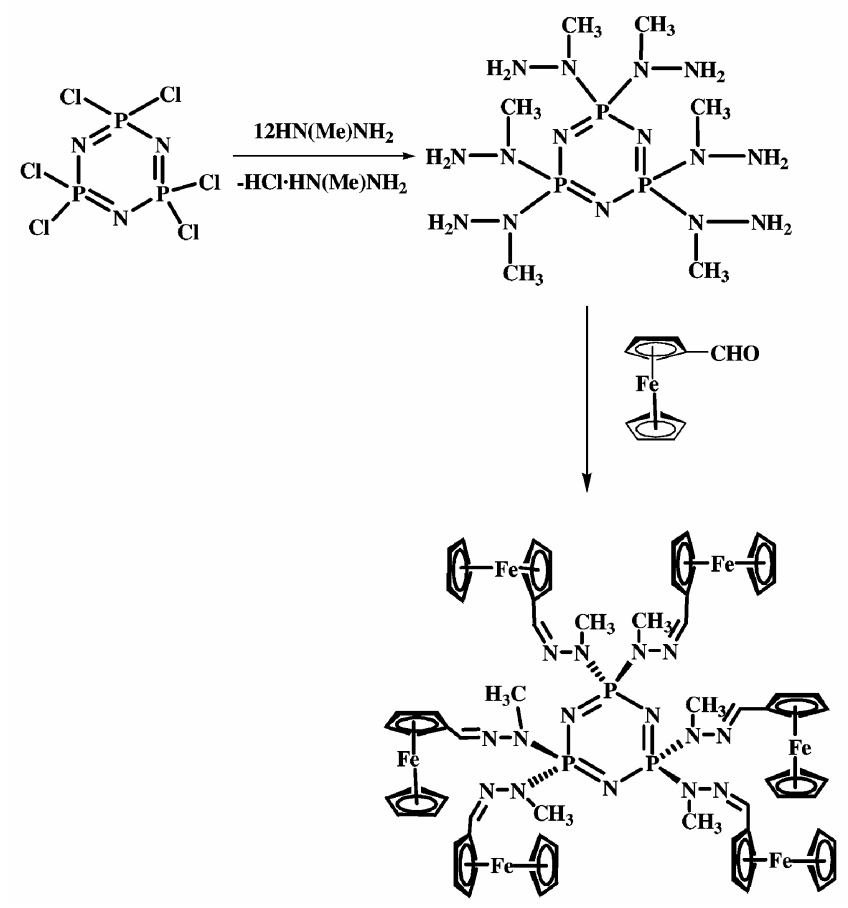

Scheme 1. Cyclophosphazene-supported multi-ferrocene assembly. 
<smiles>[R][Si]([R])([R])O</smiles>

$\mathbf{R}=\mathrm{Me}, \mathbf{P h}, c$-Hex<smiles>[R][Si]1([R])O[Si]([R])([R])O1</smiles>

$\mathbf{R}=\mathbf{C H}\left(\mathrm{SiMe}_{3}\right)_{2}$<smiles>[R][Si]([R])([R])O[Si]([R])([R])[R]</smiles>

$\left[\mathbf{R}_{2} \mathrm{SnO}\right]_{\mathbf{n}}$<smiles>[R][Si]([R])(O)O[Si]([R])([R])O</smiles>

$\mathrm{R}=n-\mathrm{Bu}$, Ph $\quad \mathrm{R}=\mathrm{Me}, \mathrm{Et}$, vinyl, $n-\mathrm{Bu}, \mathrm{Ph} \quad \mathrm{R}=\mathrm{CH}\left(\mathrm{SiMe}_{3}\right)_{2}$

Polymeric<smiles>[R][Si]1([R])O[Si]([R])([R])O[Sn]([R])([R])O1</smiles>

$\mathrm{R}=\boldsymbol{t}$-Bu, $t$-Am, Mes, $\mathrm{CH}_{2} \mathrm{SiMe}_{3}, 2,4,6-i-\mathrm{Pr}_{3} \mathrm{C}_{6} \mathrm{H}_{2}$<smiles>[R][Si]([R])(O)O[Si]([R])([R])O[Si]([R])([R])O[Si]([R])([R])O</smiles>

$\mathbf{R}=\boldsymbol{n}-\mathrm{Bu}, \mathrm{CH}_{2} \mathrm{Ph}$

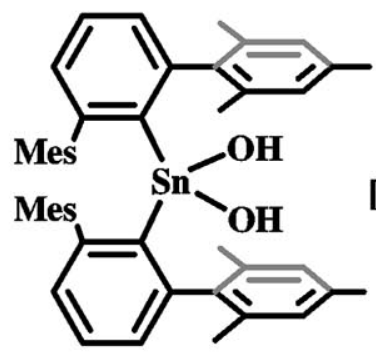<smiles>[R][Si]1(O)O[Si]([R])(O)O[Sn]([R])([R])O1</smiles>

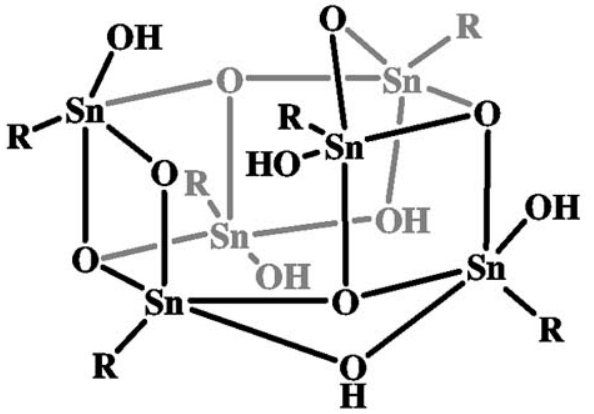

$\mathrm{R}=\mathrm{Me}, \mathrm{Et}, \boldsymbol{i}-\mathrm{Pr}, \boldsymbol{n}-\mathrm{Bu} \quad \mathrm{R}=\mathrm{CH}\left(\mathrm{SiMe}_{3}\right)_{2}$

Polymeric<smiles>[R][Sn](O)(O)O</smiles>

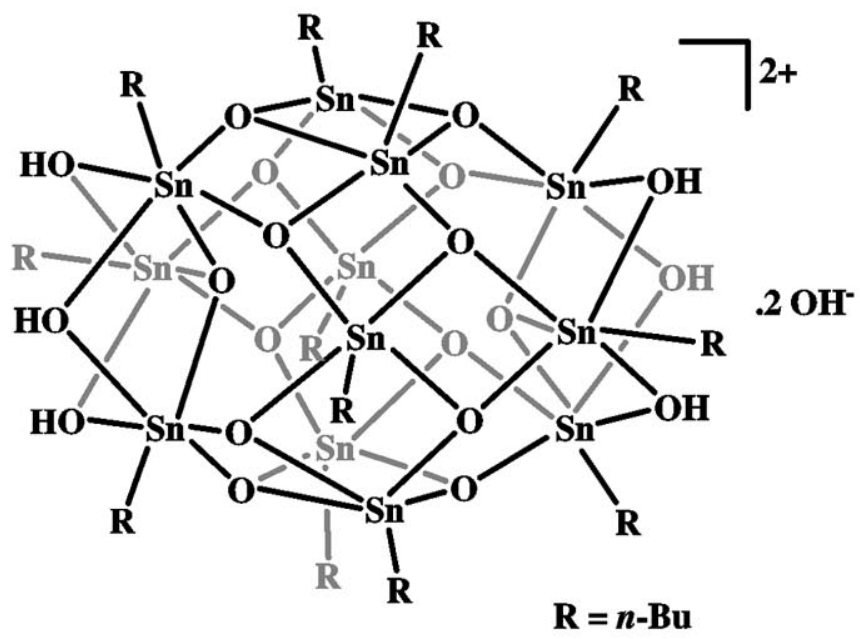

Chart 1. Various types of organotin oxides and hydroxides.

functional starburst assemblies. In this short review we present some representative examples of novel starburst type molecules containing a central stannoxane core. ${ }^{30-31}$ 
2. Organostannoxane drums and ladders containing a ferrocene periphery

As a first example to explore the applicability of the paradigm for the simultaneous construction of the core and the periphery, we chose to study the reactions of ferrocene carboxylic acid with organotin oxides and organotin hydroxides. Unlike silicon, organotin oxides and organotin hydroxides are structurally more diverse (chart 1). ${ }^{30}$

Studies carried out from our laboratory and others, ${ }^{32-37}$ revealed that a $6: 6$ reaction between a carboxylic acid $\mathrm{RCOOH}$ and the tin oxide-hydroxide, $n \mathrm{BuSn}(\mathrm{O})(\mathrm{OH})$, affords exclusively a hexameric compound $[n \mathrm{BuSn}(\mathrm{O}) \mathrm{OC}(\mathrm{O}) \mathrm{R}]_{6}$ (scheme 2). On the other hand, the main product of a $4: 4$ reaction between $n \mathrm{Bu}_{2} \mathrm{SnO}$ and a carboxylic acid is a tetrameric compound $\left[\left\{n \mathrm{Bu}_{2} \mathrm{SnOC}(\mathrm{O}) \mathrm{R}\right\}_{2} \mathrm{O}\right]_{2}$ (scheme 3 ). The hexameric compound is said to possess a drum-type structure. It contains two-fused $\mathrm{Sn}_{3} \mathrm{O}_{3}$ rings which generate six $\mathrm{Sn}_{2} \mathrm{O}_{2}$ four-membered rings as the sides of the drum. The entire $\mathrm{Sn}_{6} \mathrm{O}_{6}$ core is supported by the bidentate coordination action of $\mathrm{RCO}_{2}$ ligands. In contrast, the tetrameric compound possesses a ladder structure and contains a central $\mathrm{Sn}_{2} \mathrm{O}_{2}$ ring.

It is clear that while the assembly of the drum requires six carboxylate ligands, the formation of the ladder requires only four. If a ferrocene carboxylic acid is used, in principle, it is possible to assemble hexaferrocene and tetraferrocene architectures in a single step by changing the organotin substrates.

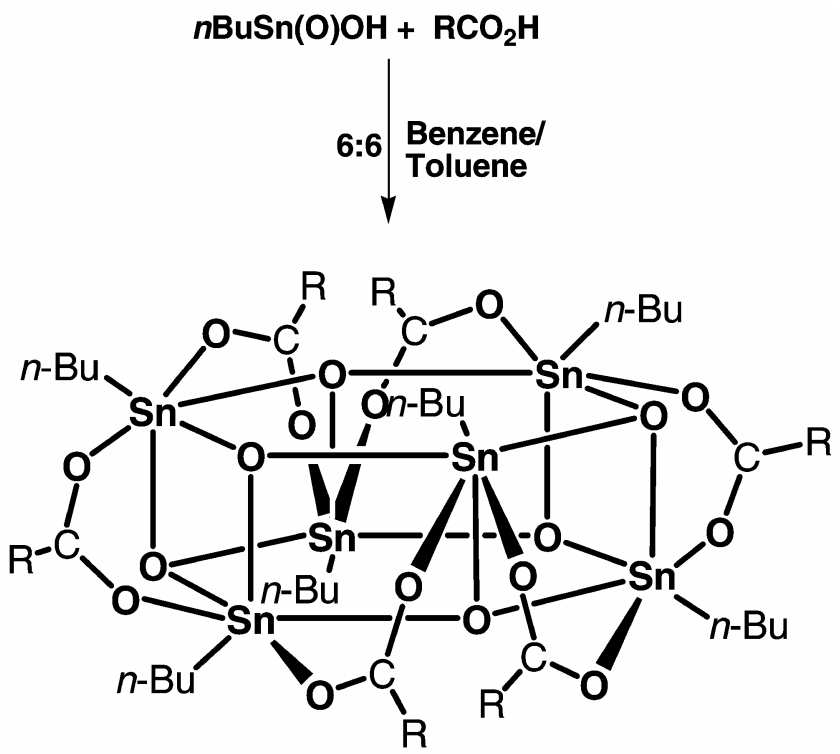

Scheme 2. Synthesis of organostannoxane drum.
This has been achieved in near quantitative yields (scheme 4). ${ }^{38-39}$

These compounds represent inorganic-core supported multi-ferrocene assemblies. These are electrochemically quite robust and do not decompose under cyclic voltammetric conditions. Utilizing this strategy other multi-ferrocene assemblies were prepared. ${ }^{39}$ It is to be noted that the nuclearity of the organostannoxanes dictates the number of ferrocenes present in the peripheries (scheme 5).

In contrast to the above, the reactions of $\mathrm{R}_{2} \mathrm{SnCl}_{2}$ $(\mathrm{R}=n \mathrm{Bu}, \mathrm{Bn})$ with ferrocene dicarboxylic acid affords macrocyclic compounds (scheme 6). Cyclic voltammetry of the benzyl derivative reveals two quasi-reversible single electron oxidations at $E_{1 / 2}=$ 0.89 and $1.05 \mathrm{~V}$ respectively. By an examination of the comproportionation constant $K_{c}$, following the Robin-Day classification, the benzyl derivative can be placed in an intermediate class between noncoupled and weakly-coupled systems (figure 1). ${ }^{40}$

\section{Multi-photoactive assemblies}

Recent interest in new organic/organometallic ${ }^{41-49}$ luminescent materials prompted us to explore stan-
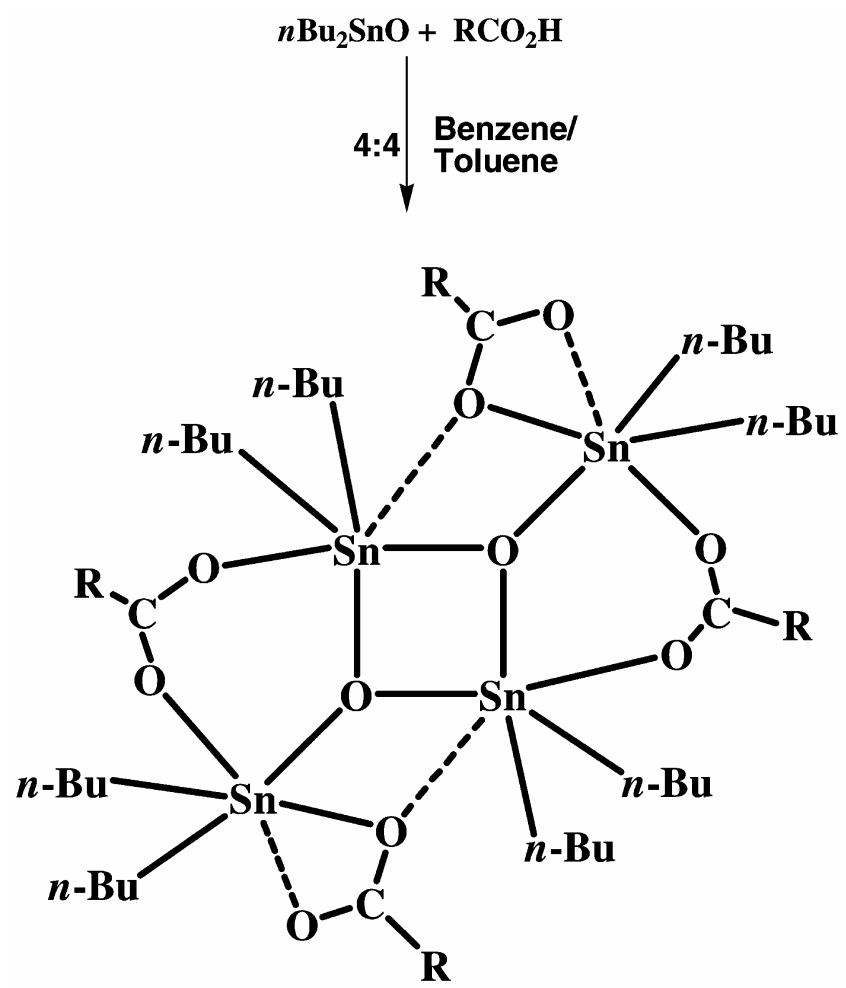

Scheme 3. Synthesis of organostannoxane ladder. 

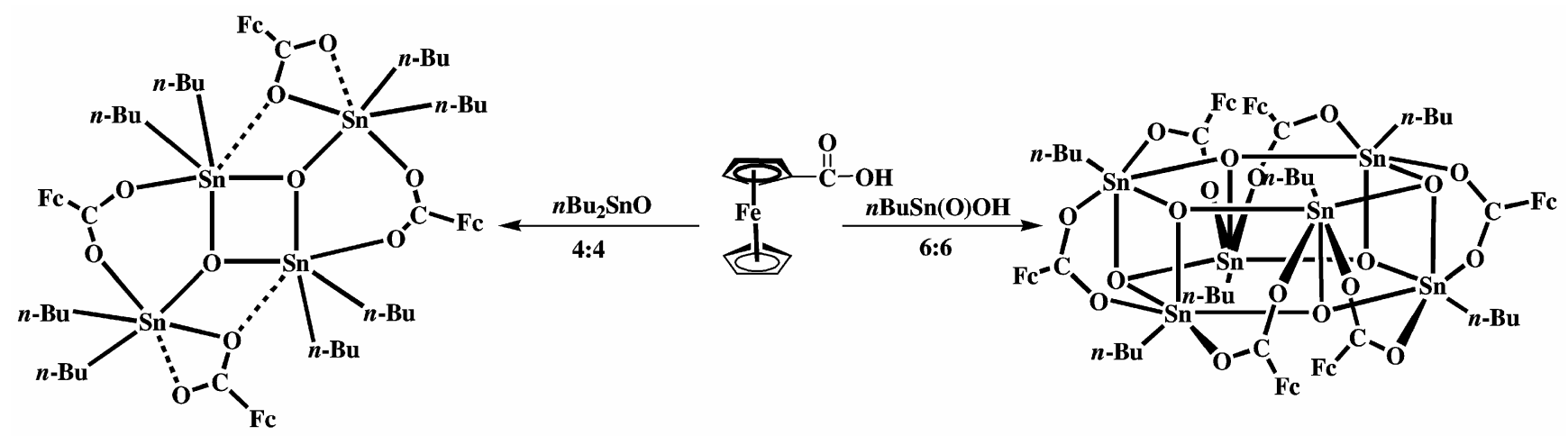

Scheme 4. Multi-ferrocene assemblies supported by organostannoxane frameworks.<smiles></smiles>

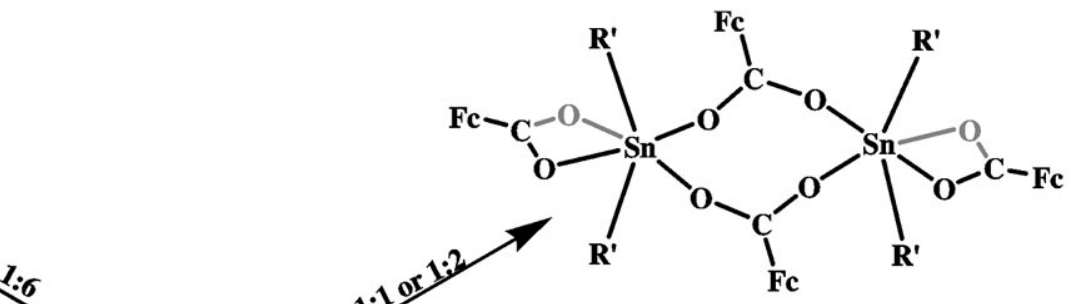<smiles></smiles>

$\left[\mathbf{R}_{2} \mathbf{S n O}\right]+$

$\mathbf{R}^{\prime}=\mathbf{P h}, \mathbf{R}=\mathbf{F c}$ [RCOOH]

$\mathbf{R}^{\prime}=\boldsymbol{n}-\mathrm{Bu}, \mathbf{R}=\mathbf{F c}$

$\mathbf{R}^{\prime}=\boldsymbol{t}-\mathrm{Bu}$

$\mathbf{R}=\mathbf{F c}$

Scheme 5. Multi-ferrocene assemblies supported by organostannoxane scaffolds.

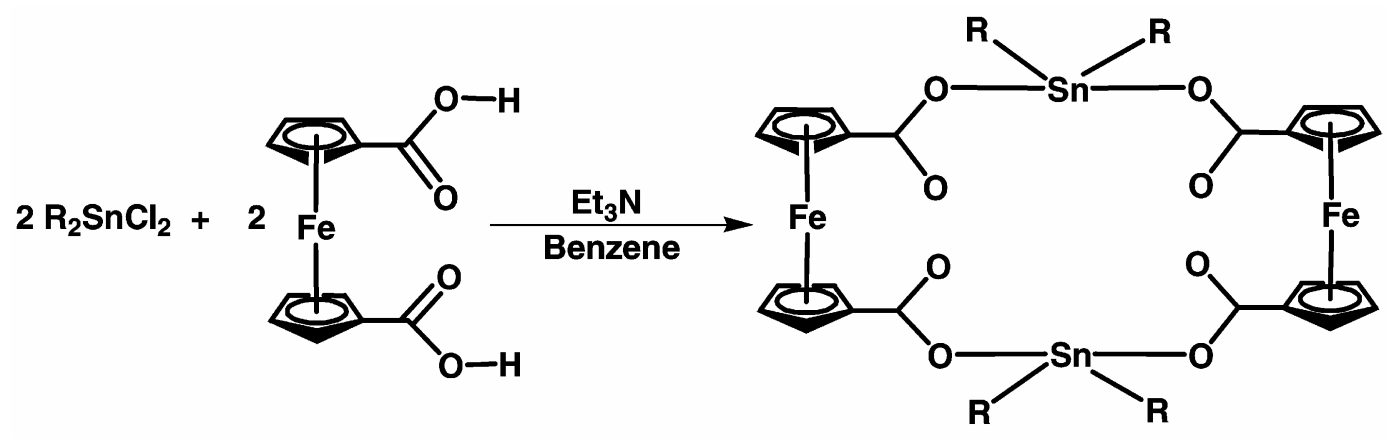

$\mathrm{R}=n-\mathrm{Bu} ; \mathrm{Bn}$

Scheme 6. Ferrocene containing macrocycles.

noxane-cored photoactive assemblies. We utilized 1- acid for preparing a new family of luminescent fluorene carboxylic acid and 9-fluorene carboxylic compounds (chart 2). ${ }^{50}$ 

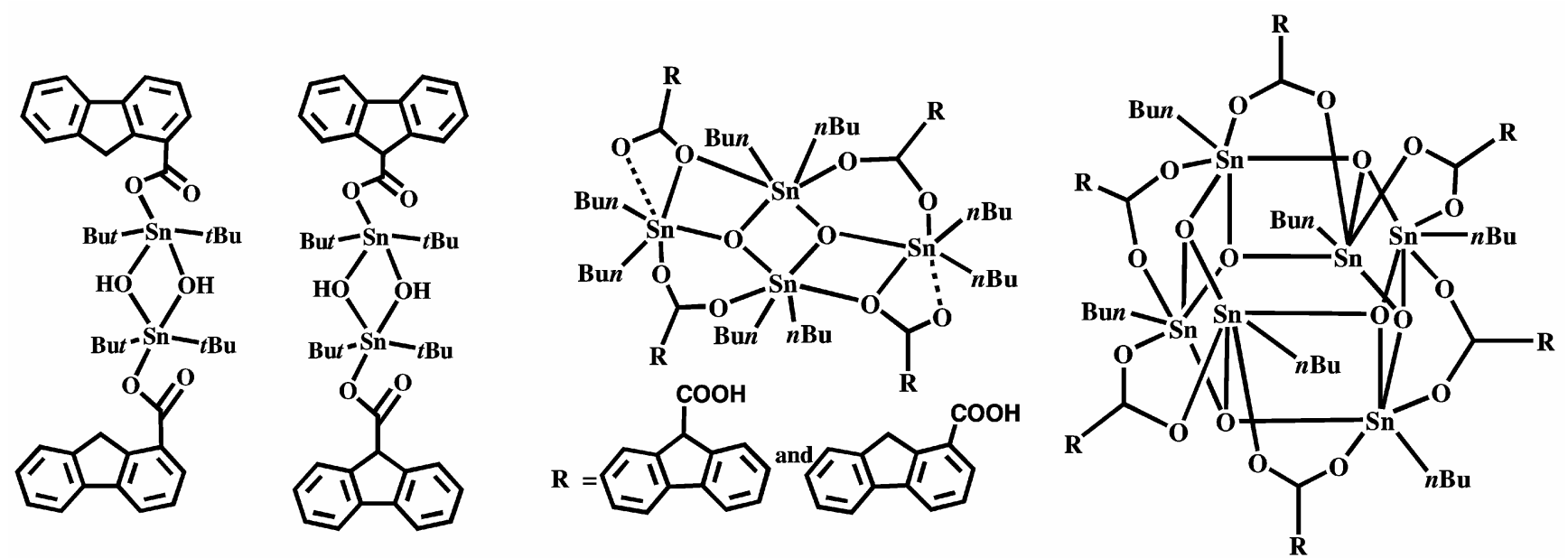

Chart 2. Organostannoxane-supported multi-fluorene assemblies.
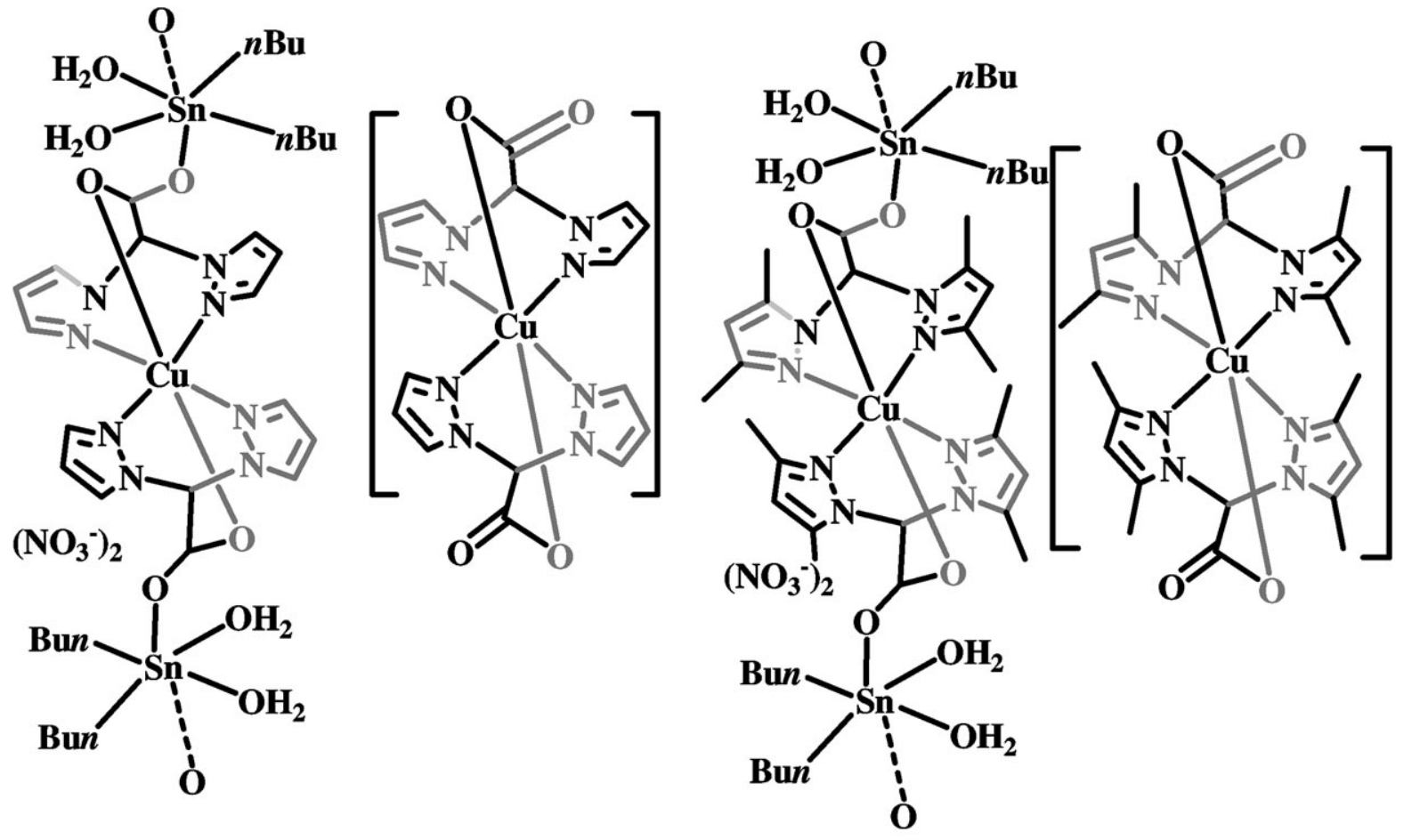

Chart 3. Heterobimetallic coordination polymer.

These organostannoxane-supported multi-fluorene compounds emit quite strongly upon excitation at their maximum absorption wavelengths. These are good blue emitters (emission maximum between 330 and $410 \mathrm{~nm}$ ). Interestingly, in solution, the fluorescence life times of all of these compounds are in the nanosecond time scale suggesting that the emission originates from the singlet excited state to the ground state.
The thin film photoluminescence spectra of these multi-fluorene compounds show slight to moderate red shifts in comparison to the solutionstate; the largest bathochromic shifts are observed for the hexafluorene derivatives (figures 2 and 3). These red shifts have been correlated with the noncovalent intermolecular interactions found in the solid-state supramolecular structures of these compounds. 


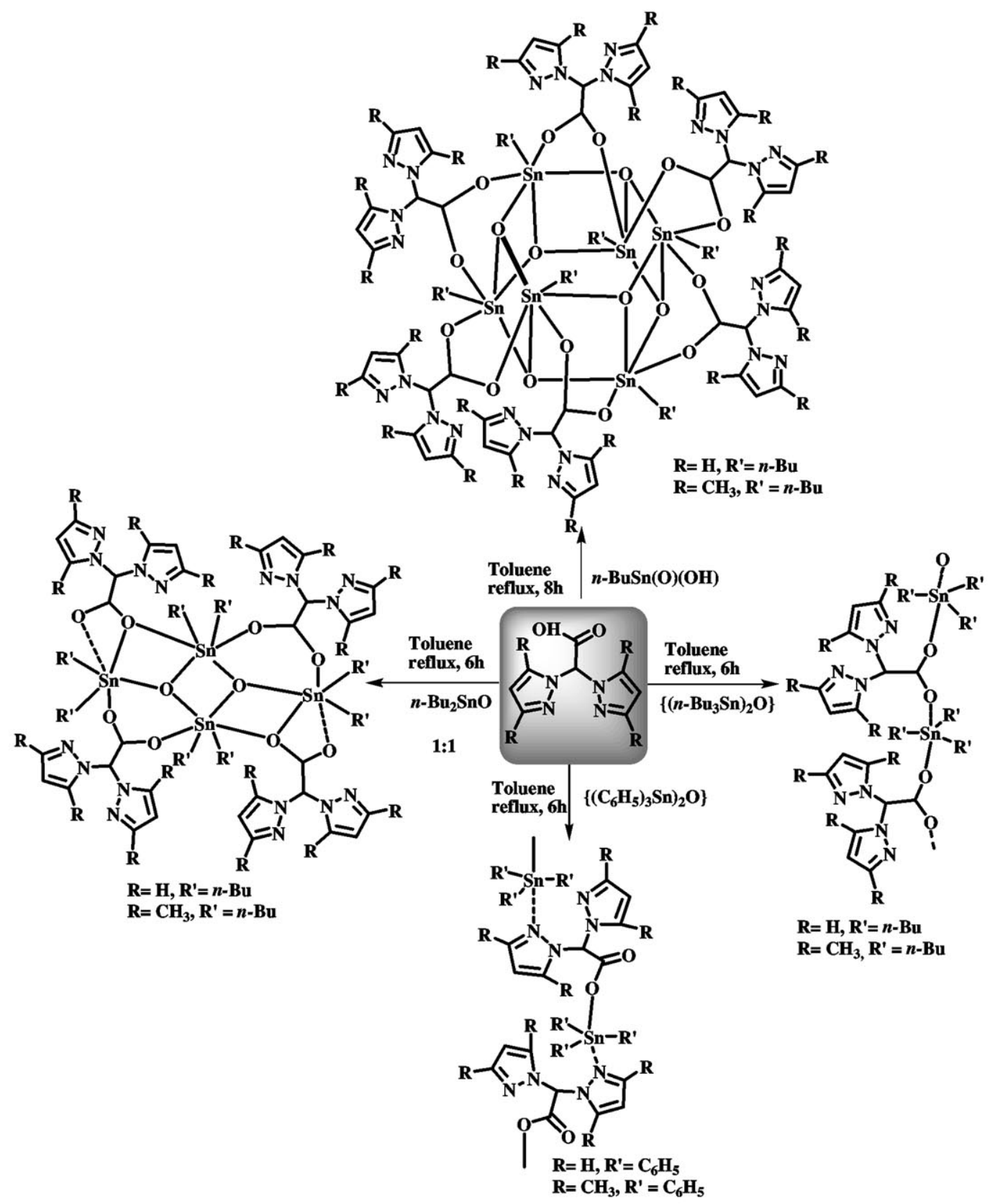

Scheme 7. Organostannoxane-supported multi-site coordination ligands.

\section{Multi-site coordination ligands}

The inertness of the stannoxane cores makes these as good platforms to build multi-site coordination ligands. Accordingly, the reaction of bis(pyrazol1-yl)acetic acid and bis(3,5-dimethylpyrazol-1-yl) acetic acid with various organotin substrates afforded a large variety of multi-site coordination ligands containing the pyrazole coordination units (scheme 7). ${ }^{51}$
The reactions of these potentially multi-site coordination ligands such as $\left[\left\{n \mathrm{Bu}_{2} \mathrm{SnOC}(\mathrm{O}) \mathrm{L}\right\}_{2} \mathrm{O}\right]_{2}$ and $[n \mathrm{BuSn}(\mathrm{O}) \mathrm{OC}(\mathrm{O}) \mathrm{L}]_{6} \quad\left[\mathrm{~L}=(\mathrm{Pz})_{2} \mathrm{CH}-\right.$ and $3,5-$ $\left.\left.\mathrm{Me}_{2} \mathrm{Pz}\right)_{2} \mathrm{CH}-\right]$ with hydrated metal salts led to the hydrolysis of the organotin carboxylates. The liberated carboxylate ligands bind to the metal ion to form homoleptic complexes such as $\mathrm{Cu}\left(\mathrm{O}_{2} \mathrm{CL}\right)_{2}$ (scheme 8).

Interestingly, in the reaction of $\left[\left\{n \mathrm{Bu}_{2} \mathrm{SnOC}\right.\right.$ $\left.(\mathrm{O}) \mathrm{L}\}_{2} \mathrm{O}\right]_{2}$ with $\mathrm{Cu}\left(\mathrm{NO}_{3}\right)_{2} \cdot 3 \mathrm{H}_{2} \mathrm{O}$ we were able to 

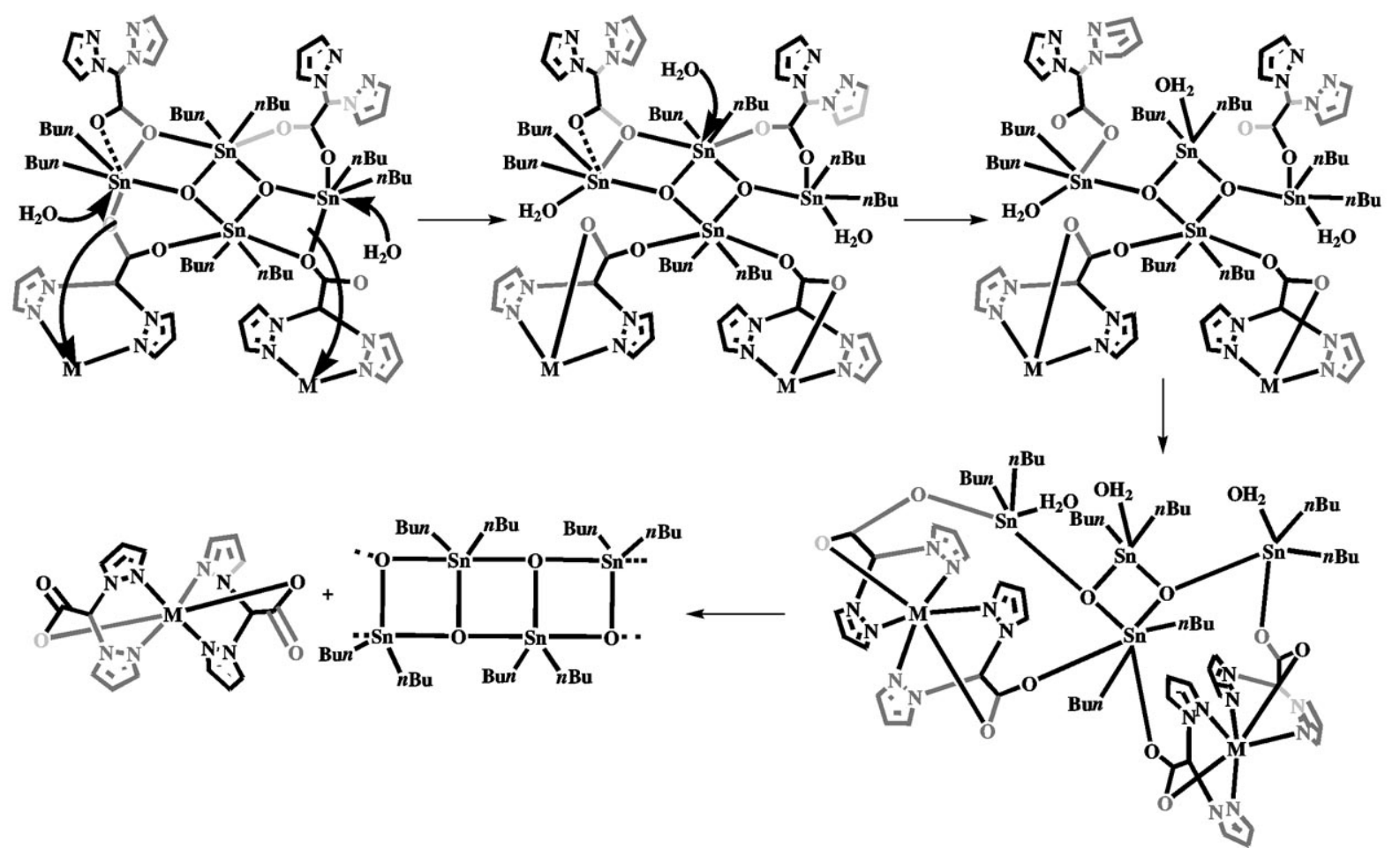

Scheme 8. Hydrolysis of $\left[\left\{n \mathrm{Bu}_{2} \mathrm{SnOC}(\mathrm{O}) \mathrm{L}\right\}_{2} \mathrm{O}\right]_{2}$ and formation of $\mathrm{M}\left(\mathrm{O}_{2} \mathrm{CL}\right)_{2} \quad\left[\mathrm{~L}=(\mathrm{Pz})_{2} \mathrm{CH}-\right.$; $\mathrm{M}=\mathrm{Cu}(\mathrm{II})$ and $\mathrm{Mg}(\mathrm{II})]$.

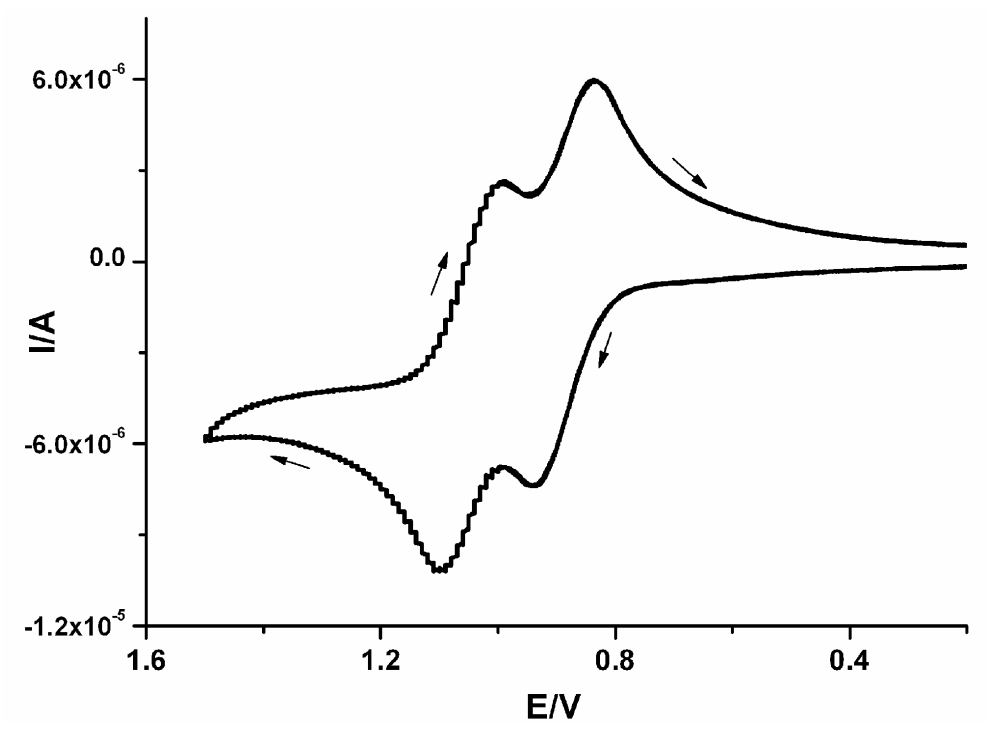

Figure 1. Cyclic voltammogram of ferrocene-containing heterobimetallic macrocycles.

isolate a heterobimetallic coordination polymer (chart 3). ${ }^{52}$

This coordination polymer represents an intermediate compound before the formation of the fully hydrolysed product.

\section{Conclusion}

The synthesis of well-defined organostannoxane assemblies provides a viable synthetic route for the preparation of a number of new and interesting den- 


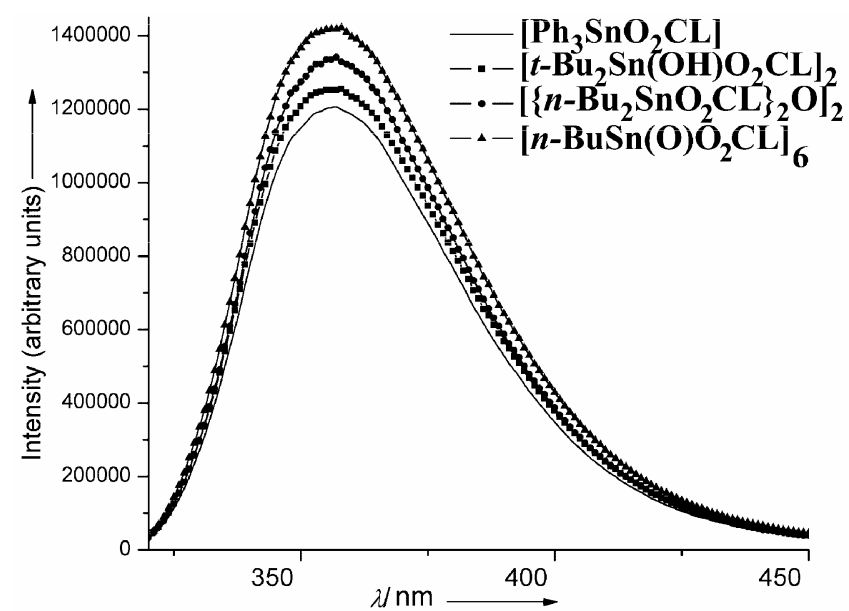

Figure 2. Solution-state normalized emission spectra of multi-fluorene assemblies in chloroform.

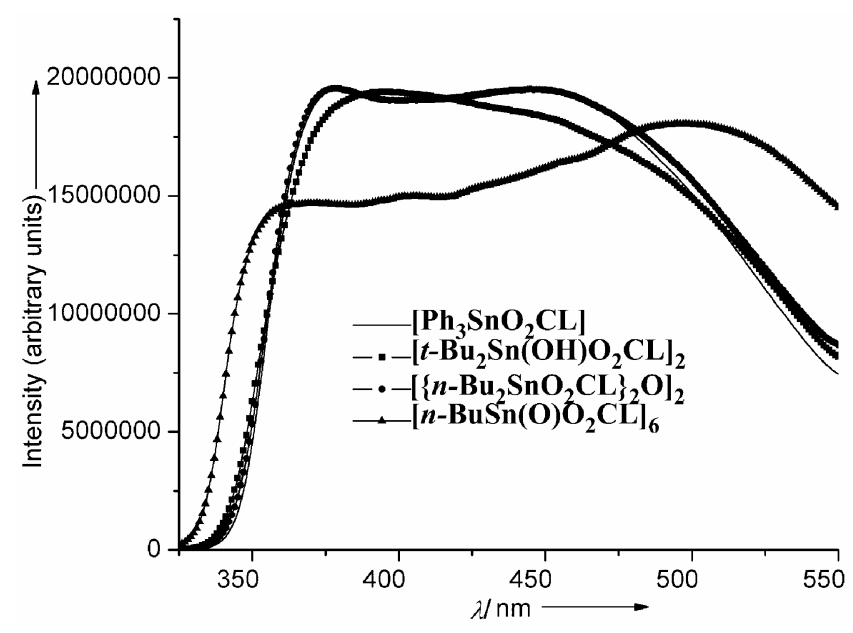

Figure 3. Solid-state normalized emission spectra of multi-fluorene assemblies.

drimeric molecules. Proper choice of the organotin substrates and carboxylic acids allows the preparation of 'designer' dendrimers containing a range of functional peripheries. As a proof of this principle we have demonstrated the synthesis of multi-electroactive, multi-photoactive and multi-site coordination ligands. We are exploring various other applications of this general synthetic paradigm.

\section{Acknowledgement}

We are thankful to the Department of Science and Technology (DST), for financial support. VC is a Lalit Kapoor chair professor at Indian Institute of Technology (IIT) Kanpur. VC is thankful to DST for a J C Bose fellowship.

\section{References}

1. Darcos V, Duréault A, Taton D, Gnanou Y, Marchand P, Caminade A, Majoral J, Destarac and Leising M F 2004 Chem. Commun. 2110

2. Koprowski M, Sebastián R M, Maraval V, Zablocka M, Cadierno V, Donnadieu B, Igau A, Caminade A M and Majoral J P 2002 Organometallics 21 4680

3. Schneider R, Köllner C, Weber I and Togni A 1999 Chem. Commun. 2415

4. Chandrasekhar V and Nagendran S 2001 Chem. Soc. Rev. 30193

5. Kim C, Jeong Y and Jung I 1998 J. Organometal. Chem. 5709

6. Casado C M, Cuadrado I, Morán M, Alonso B, Barranco M and Losada J 1999 Appl. Organometal. Chem. 13245

7. Ropartz L, Foster D F, Morris R E, Slawin A M Z and Cole-Hamilton D J 2002 J. Chem. Soc., Dalton Trans. 1997

8. Ropartz L, Morris R E, Cole-Hamilton D J and Foster D F 2001 Chem. Commun. 361

9. Murfee H J, Thomas T P S, Greaves J and Hong B 2000 Inorg. Chem. 395209

10. Gates D P, McWilliams A R, Ziembinski R, LiableSands L M, Guzei I A, Yap G P A, Rheingold A L and Manners I 1998 Chem. Eur. J. 41497

11. Kotz J C and Painter W J 1971 J. Organomet. Chem. 32231

12. Bats J W, Ma K and Wagner M 2002 Acta Crystallogr. C58 m129

13. Ma K, Lerner H-W, Scholz S, Bats J W, Bolte M and Wagner M 2002 J. Organomet. Chem. 66494

14. Shravan Kumar S, Dastagiri Reddy N, Roesky H W, Vidovic D, Magull J and Winter R F 2003 Organometallics 223348

15. Shravan Kumar S, Roesky H W, Andronesi O, Baldus $\mathrm{M}$ and Winter R F 2005 Inorg. Chim. Acta $\mathbf{3 5 8}$ 2349

16. Stasch A, Ferbinteanu M, Prust J, Zheng W, Cimpoesu F, Magull J, Schmidt H G and Noltemeyer M 2002 J. Am. Chem. Soc. 1245441

17. Shravan Kumar S and Roesky H W 2004 Dalton Trans. 3927

18. Chandrasekhar V, Senthil Andavan G T, Nagendran S, Krishnan V, Azhakar R and Butcher R J 2003 Organometallics 22976

19. Chandrasekhar V, Azhakar R, Krishnan V, Athimoolam A and Murugesa Pandian B $2006 \mathrm{~J}$. Am. Chem. Soc. 1286802

20. Ainscough E W, Brodie A M and Depree C V $1999 \mathrm{~J}$. Chem. Soc., Dalton Trans. 4123

21. Ainscough E W, Brodie A M, Moubaraki B, Murray K S and Otter C A 2005 Dalton Trans. 3337

22. Ainscough E W, Brodie A M, Depree C V, Jameson G B and Otter C A 2005 Inorg. Chem. 447325

23. Chandrasekhar V, Murugesa Pandian B and Azhakar R 2006 Inorg. Chem. 453510

24. Ainscough E W, Brodie A M, Depree C V, Jameson G B and Otter C A 2006 Polyhedron 252341 
25. Thomas K R J, Chandrasekhar V, Pal P, Scoot S R, Halford R and Cordes A W 1993 Inorg. Chem. 21 673

26. Thomas K R J, Chandrasekhar V, Pal P, Scoot S R, Halford R and Cordes A W 1993 J. Chem. Soc. 2589

27. Thomas K R J, Tharmaraj P, Chandrasekhar V, Bryan C D and Cordes A W 1994 Inorg. Chem. 335382

28. Chandrasekhar V, Krishnan V, Steiner A and Bickley J F 2004 Inorg. Chem. 43166

29. Chandrasekhar V, Krishnan V, Azhakar R, Madhavaiah C and Verma S 2005 J. Chem. Sci. 43 175

30. Chandrasekhar V, Nagendran S and Baskar V 2002 Coord. Chem. Rev. 2351

31. Chandrasekhar V, Gopal K and Thilagar P 2007 Acc. Chem. Res. 40420

32. Chandrasekhar V, Nagendran S, Bansal S, Cordes A W and Vij A 2002 Organometallics 213297

33. Chandrasekhar V, Nagendran S, Azhakar R, Ravi Kumar M, Srinivasan A, Ray K, Chandrashekar T K, Madhavaiah C, Verma S, Deva Priyakumar U and Sastry G N 2005 J. Am. Chem. Soc. 1272410

34. Kumara Swamy K C, Said M A, Nagabrahmanandachari S, Poojary D M and Clearfield A 1998 J. Chem. Soc. Dalton Trans. 1645

35. Chandrasekhar V, Schmid C G, Burton S D, Holmes J M, Day R O and Holmes R R 1987 Inorg. Chem. 261050

36. Holmes R R 1979 Acc. Chem. Res. 12257

37. Kemmer M, Dalil H, Biesemans M, Martins J C, Mahieu B, Horn E, de Vos D, Tiekink E R T, Willem R and Gielen M 2000 J. Organomet. Chem. 60863
38. Chandrasekhar V, Nagendran S, Bansal S, Kozee M A and Powell D R 2000 Angew. Chem. Int. Ed. 39 1833

39. Chandrasekhar V, Gopal K, Singh $\mathrm{P}$, Steiner A, Zacchini S and Bickley J F 2005 Chem. Eur. J. 115437

40. Chandrasekhar V and Thirumoorthi R 2007 Organometallics 265415

41. Prospects and applications for organic light-emitting devices: Burrows P E, Forrest S R and Thompson M E 1997 Curr. Opin. Solid State Mater. Sci. 2236

42. Terpetschnig E, Szmacinski H, Malak H and Lakowicz J R 1995 Bio. Phys. J. 68342

43. Bout D A V, Kerimo J, Higgins D A and Barbara P F 1997 Acc. Chem. Res. 30204

44. Guo X Q, Castellano F N, Li L and Lakowicz J R 1998 Anal. Chem. 70632

45. Ihmels H, Meiswinkel A and Mohrschladt C J 2000 Org. Lett. 22865

46. Lam M H W, Lee D Y K, Man K W and Lau C S W 2000 J. Mater. Chem. 101825

47. Halpern J 2001 Pure Appl. Chem. 73209

48. Sun S S and Lees A J 2001 Organometallics 20 2353

49. Kolosov D, Adamovich V, Djurovich P, Thompson M E and Adachi C 2002 J. Am. Chem. Soc. 1249945

50. Chandrasekhar V, Thilagar P, Steiner A and Bickley J F 2006 Chem. Eur. J. 128847

51. Chandrasekhar V, Thilagar P and Sasikumar P 2006 J. Organomet. Chem. 6911681

52. Chandrasekhar V, Thilagar P and Senapati T 2007 Eur. J. Inorg. Chem. 1004 